\title{
A broadcasting model for the music industry
}

\author{
口 \\ by Mark Fox and Bruce Wrenn, \\ Indiana University South Bend, U.S.A.
}

In 2000, sales in the global music industry amounted to approximately \$US 37 billion (International Federation of the Phonograph Industry 2001a). These figures are for sales of physical music formats, such as compact discs (CDs), cassettes, and vinyl. Despite the large scale of the music industry, there are indications that physical music sales are in the maturity stage of the product life cycle, and may even be declining for some music formats. For example, Diebold, a leading German management and technology consultancy company, observes that global music sales fell from \$41.5 billion in 1995 to \$38.5 billion in 1999 (Diebold 2001a). Also, the year 2000 witnessed a decline in value of 2.6 per cent for music sales in the United States (Recording Industry Association of America 2001a). A major contributor to this downturn was the fact that the dollar value of compact disc (CD) single sales slumped by 36 per cent in 2000 alone, owing in part to the availability of free online music (Recording Industry Association of America 2001a). By 2001, an estimated 30 million American adults - 29 per cent of all adults - had downloaded music files over the Internet (Graziano \& Rainie 2001). Younger Americans are even more likely to download music, with 53 per cent of those aged between 12 and 17 (over seven million youths) saying that they have downloaded music. This phenomenon is of particular concern to the music industry as these young consumers may, when they enter the workforce, continue to obtain music for free. There is already evi- dence that younger consumers are purchasing less music. Between 1991 and 2000, the overall market share of young consumers has declined substantially; from 18.1 per cent to 12.9 per cent for 15 to 19 year olds, and from 17.9 per cent to 12.9 per cent for 20 to 24 year olds (Recording Industry Association of America 2000b). Understandably, the research findings just summarized raise concerns about the future of music as a product, particularly with regard to young consumers, whose future music purchasing habits are being influenced by the availability of free music over the Internet.

Clearly, there is considerable pressure on the music industry to adopt new business models in order to successfully meet consumer needs in the e-commerce milieu. As Robert Picard observes, '[a] business model involves the conception of how the business operates, its underlying foundations, and the exchange activities and financial flows upon which it can be successful' (2000, p. 62). Below we discuss two pressures for new business models in the music industry, namely access to free music, and cultural and attitudinal beliefs about obtaining free music. We then turn our attention to a model that takes advantage of the opportunities offered by consumer preferences for free music, namely the so-called broadcasting model. This discussion involves, first, outlining the factors that are necessary for the use of the broadcasting model as a source of revenue and, second, discussing how the broadcasting model could successfully generate revenues.

\section{Forces for free music}

\section{Access to free music}

The development and rapid adoption of peer-to-peer technologies - such as Napster, Freenet, Aimster, and Gnutella - have provided music lovers with greater access to free music than ever before. Through these technologies, Internet users can search for music on the hard drives of other users, and then download this music to their own hard drives at no cost (Foege 2000). Viewing these technologies as a form of electronic piracy, the major music labels fear the impact that such so-called "peer-to-peer" technologies will have on their ability to generate sales from their artists. At the forefront of this concern is the Recording Industry Association of America (RIAA), a trade group representing the U.S. recording Industry. These fears are not unfounded as the threat posed by downloadable music is more significant than the previous illegal copying engaged in by consumers.

Given these distinctions, it is hardly surprising that the incidence of piracy is higher on the Internet than that directed toward physical recordings. A recent report by the International Federation of the Phonograph Industry (IFPI) estimates that worldwide piracy for physical recordings is around 36 per cent, whereas the Internet is almost totally a medium used for piracy (IFPI 2001b). In fact, the idea behind Napster, the most publicized and widely used peer-to-peer technology, is to allow people to connect to a computer network and freely trade songs. Napster thus operates through a shared server that lists addresses so that individual users can download music on the hard drives of other users. In order to prevent, or at least limit, what it viewed as music piracy, the RIAA pursued Napster so as to obtain judicial pronouncements that would set a precedent for Web-based 
music (Lee 2001). This litigation was successful; and, in February 2001, the Ninth U.S. Circuit Court of Appeals issued a ruling that requires Napster to prevent users from trading copyrighted music (Maples 2001). The Napster suit also resulted in an injunction directing Napster to block the sharing of specific music files after receiving appropriate notice from the copyright holders (in most cases, the record companies) (Napster 2001). The lawsuit against Napster appears to have successfully reduced the usage of that particular peer-to-peer service.

Despite this litigation against Napster, other sites providing free of charge peer-to-peer services still exist. A key feature of two such sites, Freenet and Gnutella, is that, unlike Napster, they are decentralized peer-to-peer networks. Napster operates a directory service of sorts, whereby users are connected with one another through Napster's centralized server. In contrast, Freenet and Gnutella have no centralized server; rather, each employs 'intelligent routing and caching so that a file can move from PC to PC anonymously, making it virtually impossible to identify who posts or downloads a transmitted file' (Pohlmann 2000, p. 59). The software for these decentralized peer-topeer networks is freely available from dozens of sites. Users who download this software then can find and connect to other users of the software who may have music or other information of interest to them (Kover 2000).

The traditional music industry is particularly threatened by the possibilities of these peer-to-peer technologies because one of its key consumer groups, those under 18, are highly computerliterate and, typically, are not old enough to obtain a credit card (Garlick 2000), thereby ostensibly reducing their ability to purchase products over the Internet. Given this widespread availability of free music, one observer suggests that, 'the challenge confront- ing the recording industry is how to prevent unauthorized copying while still offering the consumer an Internet product he or she is willing to pay for' (Pohlmann 2000, p. 59). This formidable challenge derives from the fact that the much-publicized lawsuit against Napster and the other so-called pirates will not stop the proliferation and growth of other peer-to-peer software. Compared to decentralized peer-to-peer software, Napster provided an easy target for the music industry to pursue through the legal system: Napster is a company, and it keeps a central listing of users and their corresponding directories. However, Gnutella for example, is not a company: It is a software program with over thirty variations, many of which are located in territories beyond the reach of U.S. copyright laws. The decentralized nature of Gnutella therefore makes it impossible to track users (Leung \& Lombardi 2001). Moreover, the former Napster users are not oblivious to the existence of other online alternatives sources of free music. For example, a WebNoise Research (2001) survey of 2,989 college students asked the students how they would access music online in the absence of Napster. Overall, 78 per cent said they would gravitate to other free-access sources. Only 21 per cent would gravitate to sites with legitimate MP3s, such as emusic.com and mp3.com.

Simply put, the Internet poses a severe threat to the current structure of the music. In particular, the protection of intellectual property rights on the Internet is difficult, if not impossible. Should the music industry decide to use litigation as its primary tool for combating the rise of downloading technologies - as it did in the Napster case - the widespread use of peer-to-peer technologies, combined with technological advances, virtually guarantees a staggering number of lawsuits that may overwhelm the judicial system (Magex 2000). As Reyburn (2000) observes, there is no centralized control for the
Internet; and users can take undertake numerous tactics to maintain anonymity and thus, for example, avoid service of process. Furthermore, efforts by record companies to stop the distribution of copyrighted recordings through MP3.com and Napster have proved to be a public relations disaster. Of particular concern to the music labels is the fact that the industry's response to the Napster infringements has damaged their reputation and relationship with young consumers, the industry's most desired market segment (Leung \& Lombardi 2001). For example, a survey by Quicktake in May 2000 found that over 50 per cent of online users believed that the lawsuits filed by the music industry against MP3 and Napster for copyright infringement were unjustified (Tom 2000). Ultimately then, litigation will not prove effective in combating the distribution of free music on the Internet. Put differently, as Cary Sherman observes, 'Litigation is not a business strategy. Ultimately the best response to online piracy is a legitimate alternative' (2001, p. 36).

\section{Cultural and attitudinal concerns}

It bears mentioning that the enabling role played by technology and the mere availability of free music in itself are not of paramount concern to the music industry. Rather, it is the availability of free music, when combined with consumer attitudes towards stealing copyrighted music that is of most relevance. In short, an attitudinal change has accompanied the growth of the Internet, namely the belief that information should be free (Sylva 2000). This is part of a zeitgeist that leads to a denial of ethical issues surrounding obtaining music and other services online without paying. As early as 1996 - in the days before Napster and MP3 - Adam Segal observed that "cyberspace has bred an entitlement philosophy in Internet users. The prevailing dogma is that anything available over the Internet - text, graphics, music, soft- 
ware, etc - is free, or at least should be' (1996, p. 99). More recently, Mia Garlick has suggested that:

... the growth of the Internet has also seen the rise of a hacker mentality and an entitlement philosophy. The majority of Internet users expect information and particularly music to be free. They also feel entitled to access such information or music regardless of any technological protection measures. This is partly reflected in the share and swap practices made possible by Napster and the popularity of MP3 (2000, p. 2).

Furthermore, the very nature of downloadable music leads to different consumer perceptions as to theft. A survey by the Pew Internet and American Life Project found that 78 per cent of Internet users who download music do not believe that it is stealing to save music files to their computer hard drives (Lenhart \& Fox 2000). Also, a Quicktake.com survey in the U.S. found that 80 per cent of online users do not consider that it unethical to either download or share free digital music files (Tom 2000).

Leung and Lombardi (2001) observe that the downloading of MP3 files is not merely about piracy, but actually may involve a form of protest against music companies, specifically the charging of unjustifiably high prices. For example, Latonero's (2000) survey of University of California students found that 50 per cent of respondents believed that CDs were "expensive" (another 14 per cent believed CDs to be "very expensive"). In another study - by the Music Industry News Network (2000) - 74 per cent of the respondents asserted that CDs were not reasonably priced in the offline retail market. Such shifts in the dominant cultural ethos therefore make the challenges facing the music industry even more ticklish, and make it all the more necessary that innovative business models be created to cater to changing consumer needs. We now turn our attention to one such business model.

\section{The broadcasting model}

This model is analogous to that used by television and radio broadcasters, in which the consumer receives the content free; but the broadcasters generate revenue through other means. The "broadcasting" model (also known as the free content, or equity model) is supported by the so-called "open source" movement - individuals who believe that music should be free and who call for the development of new business models that better meet the needs of consumers in the digital age. Under this model, music would be a free service, a "loss leader", with revenues being generated from associated products and services (Glynn 1999).

This model starts with the premise that the real value derives from the audience that consumes the music, rather than from the product itself. Put another way, the audience is the product that is delivered to the marketers. The broadcasting model is also predicated on the belief that music has widespread social appeal and therefore significant potential for delivering a large audience to marketers. Clearly, the key to the use of the broadcasting model as a revenue source centers around an organization's success in three areas: selling advertising space to other companies, mining consumer data and selling that data to other organizations, and selling related goods and services. Each of these revenue streams will now be discussed, followed by a listing of data mining and analysis software needed to help generate these revenue streams, and finally a model and example demonstrating how this model could operate for a music company.

\section{Revenues via advertising}

Perhaps the greatest attraction of online business models is that they allow for targeted advertising and one-toone marketing (Bakos 2001; Diebold 2001b). Individual consumers clearly place differing levels of importance on listening to and purchasing music. Also, Mizerski et al. observe that, "the consumption of music appears to be more of an emotionally-based activity than many of the products traditionally addressed by marketing' (1988, p. 79). That individuals have different emotional attachments to music offers an opportunity for marketers to tailor product offerings and marketing efforts to individual consumers or distinct groups. Furthermore, the provision of music with advertising can have a major impact on marketers who wish both to monitor the effectiveness of their advertisements and to target consumers more effectively. As Sean Carton observes:

... what if the consumption of that entertainment could be measured exactly in real time? Instead of relying on indirect measures to judge the effectiveness of our ads, or using indirect measures to find out about the audiences, we would be able to know exactly who is watching and/or listening, exactly what each person is watching and/or listening to, and when he/she is watching and/or listening. ... Instantly you have access to pinpoint user data that can then be used to market the stuff that people can't transmit across the Internet - the tangible hard goods - to the people waiting to buy them $(2000$, p. 2).

Also, consumers with high music involvement are more likely to be amenable to relationship marketing tactics. Music labels and musicians can potentially use the Internet to reduce their search costs - those costs associated with identifying qualifying buyers of their products, such as market research and advertising (Bakos 2001). In short, the web offers the opportunity for the music industry to better understand and meet the needs of consumers (Magex 2000). As Thomas Dolby Robertson observes:

What the Web offers is a unique opportunity to understand for the first time, what really makes the public tick. Who they are, why they 
buy, what else they do when we're not buying $C D$ s. There's never been a marketing platform quite like it. Armed with this information, a label ought to be able to precisely target the correct demographic for its artist, and cut out the wastage in the marketing budget (2000).

Making money by selling space to advertisers on a web-site offering free music will require an improvement on the less than $1 \%$ click through rate for most web banner ads. To improve consumer click-through rates will necessitate the use of the latest techniques in customized target marketing, or affinity marketing - targeting goods and services to groups of people joined by common interests (Miles 2001). The Internet offers technologically advanced means of tracking web-site visitors interests, then grouping people with common interests and selling ad space to advertisers seeking to reach those people. Such consumer groups can be compiled by using neural networks to search for common threads in downloaded music or purchases made at the site, or through consumer volunteered information using a process such as Amazon's Listmania. Listmania permits consumers to establish wish lists of goods or services, favorite artists or music, videos, etc. and share their lists with other site visitors. Another Amazon service is Purchase Circles, which lists top purchases of aggregated users from various organizations, such as, Boston University students. Both Listmania and Purchase Circles are affinity programs that help develop Internet communities of people with similar interests. Amazon reports that Listmania customers are much more frequent visitors than typical customers. The frequency of site visits plus the common interests of the communities makes them an attractive target for advertisers seeking to do highly focused marketing.

One web-site that presently uses the broadcasting model to generate revenues through advertising is playj. Us- ers visiting playj for the first time are prompted for personal information, including their interests and e-mail address. The visitor can subsequently download or stream music for free. However, when the track is played, an advertisement from a "sponsor" is displayed on the computer screen. This advertising is targeted based on demographics, content, geography, and user behavior (http:/ /www.everad.com/technology.html). Furthermore, a real-time reporting system provides around-the-clock usage information to advertisers, who can then evaluate the effectiveness of their promotional efforts. EverAd, the company that provides the playj technology shares the resultant advertising revenues with content providers and website affiliates.

\section{Revenues via sale of data}

The sale of consumer data to marketers has become a multi-billion dollar business. Marketers are constantly seeking to use data about consumers to become more efficient in targeting their marketing appeals. "One-to-one marketing” (Peppers \& Rogers 1993) has become a catch-phrase in marketing to describe the objective of finding and reaching only those consumers whose profile suggests a high probability of becoming a good customer. Data is also used to filter through existing customers to determine those who should receive top quality (i.e., high cost) customer service. "Web-lining" when data is generated from web-site visits and other on-line databases - facilitates this objective (Stepanek 2000). This practice is similar to the long existing practice of "redlining" customers and reserving vigorous customer service for only the best customers of a firm. In the case of both potential and existing customer databases, organizations are discovering the positive impact on profits when they can use data to eliminate unproductive marketing efforts. Hence, music companies can "trade" free music for information from web-site visitors that is of value to organizations seeking to market to that target audience, thereby generating a revenue stream from the broadcasting model using this means. A German company, the Diebold Group (2001b), in a paper entitled "Wanted: A Survival Plan for the Music Industry" has proposed this method of generating revenue. Under the Diebold model, users would access a marketing platform; provide information about themselves; and, in exchange, receive free access to music content. To continue their "free subscription", consumers would need to answer more questions each month. Data on consumer demographics and preferences could then be sold to advertisers and other interested parties.

\section{Revenues via cross-selling}

Cross-selling consists of "promotion in which the manufacturer of one brand attempts to sell another brand to the same customer, or the purchase of one product is used to stimulate the selection of another, often unrelated product.' (Harrell \& Frazier 1999). Music companies could use software programs to identify those goods and services they, or other companies with whom they could establish synergistic partnerships, produce that have potential to be cross sold with free music on the web site. Relationship marketing programs (Kotler 2000) are rich in cross selling strategies and could form the basis of using the broadcasting model for generating revenues from products other than the music itself. Berry and Parasaraman (1991) have identified two value-building approaches companies can achieve via relationship marketing. The first approach involves adding financial benefits - using frequency marketing programs (FMPs) such that after a certain number of web site visits the consumer is eligible for discounts or other rewards on products offered at the site. The second approach is adding social benefits - building brand communities by providing 
Figure I: Generation of Revenue Using a Broadcasting Model

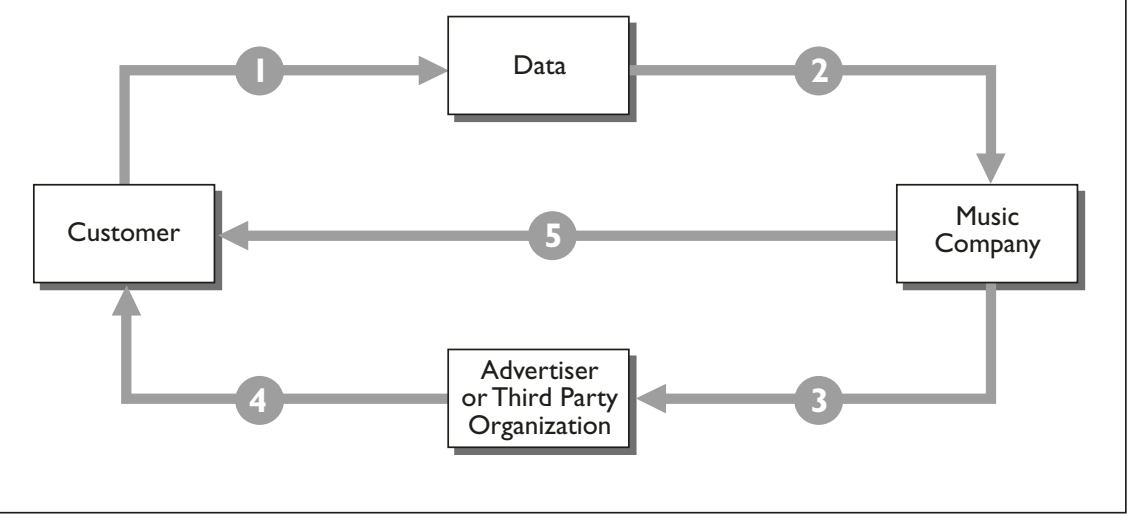

the means for consumer to establish social bonds with like-minded people via the web-site. Access to these communities via the web-site enhances access to consumers, increasingly the possibility of cross-selling goods and services and integrating consumption of specific goods or services as an integral part of the social network.

Generating revenues from one or more of these strategies requires the use of six types of software programs to effectively generate, collect, and analyze consumers' data (Green 1999):

1. Managing Customer Contacts: Software that pulls together a variety of ways the consumer interacts with a company. The "Big Five" music companies are in other entertainment related businesses as well, generating multiple interactions with consumers.

2. Customer Service: Software that automatically replies to, routes, or segments e-mail. This is needed to more effectively respond to customer interests and help build a relationship marketing program.

3. Ad Targeting: Software that track ads across a network of web-sites monitoring who is clicking on the ads, how often, and whether ads lead to sales.

4. E-Mail Direct Marketing: Software that sends highly targeted e-mail messages to specific consumer email addresses.
5. Data Analysis Engines: Software designed to accumulate and analyze information from numerous inplace systems.

6. Supply Chain and Logistics: Software that quickly translates on understanding of customers' tastes and purchases into production schedules and supplier orders.

\section{How the Broadcasting Model Might Work}

Figure One portrays a model that demonstrates the means by which a music company (hereafter, MC) could use the software programs described above to generate revenues via sale of information, ad space, or cross-selling of associated goods and services.

Each of the five numbered steps is described below:

1. Consumer's Actions Generates Data

A. Buys a ticket for a concert by artist under contract to MC.

B. Subscribes to MC cable channel.

C. Enters a contest for attending a recording session by $\mathrm{MC}$ artist.

D. Fills out a warranty card for DVD player made by MC division

E. Clicks on a request for dealer location at MC web-site for retail chain operated by MC.

F. Calls a toll free number or sends an e-mail message requesting help in operating MP3 player made by MC division.
G. Navigates through web-sites of MC clicking on purchases, more information, links, ads, etc.

H. Consumers access a marketing platform, provide information about themselves to maintain a subscription to free music access on MC web-site.

2. Data is organized and analyzed by company

A. MC uses customer contact integrative software to pull all of the contacts made by consumer's actions such as those in Step 1 into a single database.

B. Integrated into the database is ad tracking software that identifies how the consumer has responded to ads placed on MC web-sites across MC's divisions, and e-mail response, routing, and segmentations software combines the e-mail tracking and ad tracking data with data on consumers actions to generate an in-depth profile of each consumer in the database.

C. Data analysis engines combine consumer information with sales, inventory, and logistics databases to identify best consumer prospects for specific types of music or other product lines of the MC, emerging trends in the music business, and predict consumers interest in new lines of products or music forms based on analysis of database.

D. Information from the database analysis engines is fed into supply chain and logistics software to generate production schedules and supplier orders for music videos, CD's, electronics, etc.

3. MC sells information on consumers or ad space to advertisers and other third party organizations.

A. The MC's processing of consumer information in their database permits an in-depth profile of consumers, including their response to ads, thereby generating information of value to those compa- 
nies seeking to advertise on $\mathrm{MC}$ web-site to reach this target market with goods and services not sold by MC (e.g., clothing, athletic equipment, travel services, etc.)

B. Information generated from consumer actions could also be combined with information volunteered by consumers (see $1 \mathrm{H}$ ) to sell to other third party organizations interested in targeting these consumers via their own marketing channels.

4. Advertisers and other third parties use MC web-site or other means to reach targeted consumers.

A. MC may obtain revenues either by selling ad space as in 3 , or obtain revenues on a per capita basis every time the advertiser is successful in getting a response from the consumer to a MC web-site ad.

B. MC may obtain revenues either by selling consumer information to third party organizations as in 3, or generate revenues by partnering with third party organizations that also sell to these consumers in producing goods or services that can be cross-sold at MC website. This partnering would be for goods and services that are not already offered by MC. They could also generate cross-selling revenues when these goods and services were sold at the partner's web-site.

5. MC directly interacts with consumer

A. Consumer visits $\mathrm{MC}$ web-site to obtain free downloadable music (or trade information about himself/herself for music) and clicks on ad (MC generates ad space revenue), or makes purchase (MC revenues from cross-selling), or links with another web-site (MC revenues from cross-selling partnership).

B. MC sends direct marketing e-mail to consumer using e-mail targeting software. E-mails are targeted to specific consumers, offering new releases by consumer's favorite artists, "preferred customers" seating at nearby concerts, "limited edition" clothing with favorite artist endorsement, and other relationship marketing appeals.

\section{Discussion}

Free music models are potentially attractive to digital music providers in light of the youth of many fans. The RIAA reports that in the year 2000, 21.8 per cent of music sales were to consumers aged nineteen or younger (RIAA 2001b). However, as Mia Garlick observes, the disadvantage of such models stems from consumers' devaluating music: '[This] makes it harder for business models which charge to compete and arguably provides a disincentive for artists' (2000, p. 9). To provide music for free would also jeopardize critical ties with retailers and radio. Perhaps, of greater concern, the record companies would have to radically rethink how they deliver products. In light of the role that strategic planners in the major record companies played in developing current strategies, it is no doubt difficult for them to re-conceptualize their business in light of the dramatic technological and social changes taking place. As Henry Mintzberg (1989) observes, past strategy strongly influences current strategic choices. In this regard, clearly the music industry has operated with essentially the same business model for much of the twentieth century (Garofalo 1999; Ponce 1999). In particular control over the distribution of a physical product has been central to performance of the industry for many years. It is one thing for music executives to make the leap from music as a product to music as a service, but quite another to see sources of revenue lying predominantly outside the music itself. Certainly, music industry executives are not alone in being faced with a changing industry environment, where the very nature of their product offering can be transformed (see, for example, Zerdick et al. 2000). Unfortunately, arrogance also appears to have played a role in the slowness of the Big Five to respond to changing environmental forces. Take, for example, the following observation by Richard Haring in his book Beyond the Charts:

Record companies were slow to recognize the perils to their business spawned by the rise of the Internet. As late as 1998, many companies did not have staff whose job it was to monitor activities on the Net. Most senior executives, when they paid attention at all, dismissed the net as just another passing fad, the CB radio of the 1990s. Many executives privately felt that any changes that did develop would happen long after they were safely retired.

As such, the entrenched executives felt that supporting a new philosophy of distributing music, one which embraced a direct relationship with the consumer, was something that needed to be avoided at all costs. Their attitude amounted to a stone wall: we work for companies that have multinational reach and resources. We have the relationships. And more to the point, we have the artists under contract. We control the system. There is no need to change (2000, pp. 9-10).

Irrespective of these human, strategic concerns it is clear that music companies could still gain advertising revenue (or revenue-sharing arrangements) through licensing their music for subscription or sale. Hence, it is unlikely that the major music labels will adopt a broadcasting model. In any event, some of the insights provided in this paper will be useful to music labels, whatever business models they may adopt. 


\section{References}

Bakos, Y. 2001, 'The emerging landscape for retail e-commerce,' Journal of Economic Perspectives, vol. 15, no. 1, pp. 69-80.

Berry, L.L. \& Parasuraman, A. 1991, Marketing Services, Free Press, New York.

Carton, S. 2000, Will the Digital Music Industry Survive? 27 September [Online]. Available: http:// www.clickz.com [Accessed 1 Sept. 2001]

Diebold 2001a, Wanted:

A Survival Plan for the Music Industry

- Chapter One: problem areas of the recording industry [Online]. Available: http://www.musicdish.com [Accessed 1 Sept. 2001].

Diebold 2001b, Wanted: A Survival Plan for the Music Industry - Napster and the Consequences [Online]. Available: http://www.diebold-consulting.com [Accessed 1 Sept. 2001].

Foege, A. 2000, 'Free music and the death of the album,' Spin, September, pp. 159-162.

Garlick, M. 2000, Pricing Recorded Music in an Online World [Online]. Available: http://www.gtlaw.com.au/ pubs/pricingrecordedmusic.html [Accessed 1 Sept. 2001].

Garofalo, R. 1999, 'From music publishing to MP3: music and industry in the twentieth century,' American Music, vol. 17, no. 3, pp. 318-353.

Glynn, S. 1999, Making Money from Free Services [Online]. Available: http://www.mercermc.com [Accessed 1 Sept. 2001].

Graziano, M. \& Rainie, L. 2001, The Music Downloading Deluge, Pew Internet Tracking Report. Pew Internet \& American Life Project [Online]. Available: http://www.pewinternet.org/ reports [Accessed 1 Sept. 2001].

Green, H, 1999, The information goldmine,' Business Week E-Biz, 26 July, pp. EB17-EB30.
Haring, B. 2000, Beyond the Charts: MP3 and the Digital Music Revolution, OTC Books, Los Angeles.

Harrell, G.D. \& Frazier, G.L. 1999, Marketing, Prentice-Hall, Upper Saddle River, NJ.

International Federation of the Phonograph Industry 2001a, Recording Industry World Sales 2000 [Online]. Available: http://www.ifpi.org/statistics/ worldsales.htm [Accessed 1 Sept. 2001].

International Federation

of the Phonograph Industry 2001b, IFPI Music Piracy Report [Online]. Available: http://www.ifpi.org/library/ piracy2001.pdf [Accessed 1 Sept. 2001].

Kotler, P. 2000, Marketing Management, Prentice-Hall, Upper Saddle River, NJ.

Kover, A. 2000, 'Napster: The hot idea of the year,' Fortune, June 26, pp.129-136.

Latonero, M. 2000, Survey of MP3 Usage: Report on a University Consumption Community, Norman Lear Center, Annenberg School of Communication, University of California [Online]. Available: http://entertainment.usc.edu/ publications/mp3.pdf [Accessed 1 Sept. 2001].

Lee, H.C. 2001, 'Making the net safe for record labels,' The Standard, [Online] February 12. http://www.thestandard.com [Accessed 1 Sept. 2001].

Lenhart, A. \& Fox, S. 2000, Downloading Free Music: Internet Music Lovers Don't Think it's Stealing, Pew Internet and American Life Project's Online Music Report [Online]. Available: http://www.pewinternet.org [Accessed 1 Sept. 2001].

Leung, L. \& Lombardi, R. 2001, 'MP3: music for the masses,' Risky Business, vol. 2A, pp. 18-20 [Online]. Available: http://www.pwc.com [Accessed 1 Sept. 2001].

Magex 2000, 'Online music piracy, "I fought the law and the law ...", [Online]. Available:

http://www.magex.co.uk [Accessed 30 June 2001].
Maples, J. 2001, 'Napster gets played,' Red Herring, February 14. [Online] [Accessed 1 Sept. 2001].

Miles, S. 2001, 'People like us,' Wall Street Journal, 23 April, p. R30.

Mintzberg, H. 1989, Mintzberg on Management: Inside Our Strange World of Organizations. Free Press, New York.

Mizerski, R., Pucely, M., Perrewe, P. \& Baldwin, L. 1988, An experimental evaluation of music involvement measures and their relationship with consumer purchasing behavior,' Popular Music and Society, vol. 12, pp. 79-96.

Music Industry News Network 2000, MI2N Survey Results:

Retail CD Pricing [Online]. Available: http://www.mi2n.com/rping.phb3 [Accessed 1 Sept. 2001].

Napster 2001, District Court Preliminary Injunction, March 5 [Online] Available: http://dl.napster.com/010305injunction.pdf [Accessed 1 Sept. 2001].

Peppers, D. \& Rogers, M. 1993, The Oneto-One Future, Doubleday/Currency, New York.

Picard, R.G. 2000, 'Changing business models of online content services - their implications for multimedia and other content producers,' The International Journal on Media Management, vol. 2, no. 2, pp. 60-68.

Pitofsky, R., Anthony, S.F., Thompson, M.W., Swindle, O. \& Leary, T.B. 2000 [Online]. Available: http://www.ftc.gov/ os/2000/09/musicstatement.htm [Accessed 1 Sept. 2001].

Pohlmann, K.C. 2000, 'Music wars,' Scientific American, vol. 283, no. 5, pp. 56-60.

Ponce, B. 1999, 'The impact of MP3 and the future of digital entertainment products,' IEEE Communications Magazine, September, pp. 68-70.

Reyburn, S.B.A. 2000, 'Fair use, digital technology, and music on the Internet,' University of Pittsburgh Law Review, vol. 61, pp. 991-1022. 
RIAA 2001a, Recording Industry

Releases 2000 Manufacturers'

Shipments and Value Report [Online].

Available: http://riaa.org/MD-

Tracking.cfm [Accessed 1 Sept. 2001].

RIAA 2001b, The Recording Industry

Association of America's 2000 Consumer

Profile [Online]. Available: http://riaa.org/

PDF/2000_consumer_profile3.pdf

[Accessed 1 Sept. 2001].

Robertson, T.D. 2000, The Upside of

Music on the Web-Part Two [Online].

Available: http://www.riaa.org/

Guest_Column0301.cfm [Accessed 1 Sept.

2001].

Segal, A.P. 1996, 'Dissemination of digitized music on the Internet: A challenge to the Copyright Act,' Computer and High Technology Law Journal, vol. 12, pp. 97-138.

Sherman, C. 2001, 'Music on the Internet: a new world is waiting,' The Brookings Review, vol. 19, no. 1, pp. 35-37.

Stepanek, M. 2000, 'Weblining,' Business Week E-Biz, April 3, pp. EB26-EB34.

Sylva, J.B. 2000, 'Recent trends in copyright law; relevant technologies and emerging business models,' Loyola of Los Angeles Entertainment Law Journal, vol. 20, pp. 217-241.

Tom, J. 2000, QuickTake Snap Shot: It's Okay to Download Free Music Files According to 80\% of Online Music Users [Online]. Available: http://www.quicktake. com/qt/static/files/DigitalMusicFinal.pdf [Accessed 1 Sept. 2001].

Webnoise Research 2001, How will you Acquire Music in the Absence of Napster [Online]. Available: http://www.webnoise. com/research/ [Accessed 1 Sept. 2001].

Zerdick, A., Picot, A., Schrape, K., Artope, A., Goldbammer, K., Lange, U.T. and Lopez-Escobar, E. 2000, E-conomics: Strategies for the Digital Marketplace, Springer Verlag, New York.

\section{About the Authors}

Mark Fox (mfox1@iusb.edu) is Associate Professor of Management and Entrepreneurship at Indiana University South Bend. The major focus of Dr. Fox's current research is on how electronic commerce is transforming the music industry. Other current research project relate to online auctions, the use of the Internet by exporters, and online gambling. Dr. Fox has published over 90 papers, including articles for the Journal of Management Studies, International Small Business Journal, Journal of Entrepreneurial Behaviour and Research, and Psychology and Marketing.

Bruce Wrenn (bwrenn@iusb.edu) is Associate Professor of Marketing at Indiana University South Bend. His research focuses on e-commerce business models. He has authored five books and numerous articles on marketing strategy and marketing research topics.

\section{Acknowledgements}

The authors wish to thank the two anonymous reviewers for their comments. We are also indebted to Brenda Knowles and Fred Naffziger, Professors of Business Law at Indiana University South Bend, for helpful suggestions on earlier drafts of this paper. 